\title{
A new set of endogenous reference genes for gene expression studies of porcine stomach
}

\author{
M. Oczkowicz ${ }^{1,3}$, M. Różycki ${ }^{1}$ K. Piórkowska ${ }^{1}$, A. Piestrzyńska- \\ Kajtoch $^{2}$ and B. Rejduch ${ }^{1}$
}

\author{
National Research Institute of Animal Production, \\ ${ }^{1}$ Department of Genetics and Animal Breeding, \\ ${ }^{2}$ Department of Immuno and Cytogenetics \\ 32-083 Balice, Poland
}

(Received 28 October 2009; revised version 23 September 2010; accepted 26 November 2010)

\begin{abstract}
Gene expression analysis by Real-Time PCR requires careful selection of endogenous reference genes to obtain accurate results. We evaluated usefulness of six reference genes to expression studies of porcine stomach. We selected genes which were recently described as very stable (RPL27, RPS29, RPS13, OAZ1) and two commonly used housekeeping genes (GAPDH, ACTB). Our results indicate that $O A Z 1, R P S 29$ and RPL27 are more suitable reference genes than $A C T B$ and GAPDH in expression studies of porcine stomach. In our study the most stable genes were $O A Z 1 \quad(\mathrm{M}=0.856)$, $R P S 29(\mathrm{M}=0.862)$ and $R P L 27(\mathrm{M}=0.892)$, while $A C T B(\mathrm{M}=1.03)$ and $\operatorname{GAPDH}(\mathrm{M}=1.005)$ were less stable. RPS13 $(\mathrm{M}=1.913)$ appeared to be highly unstable.

Set of three the most stable genes has been used to compare ghrelin (GHRL) expression in two different regions (diverticulum ventriculi and fundus ventriculi) of porcine stomach. Ghrelin mRNA was highly expressed in both regions of stomach, however level of GHRL mRNA was approximately 5 -fold higher in fundus ventriculi than in diverticulum ventriculi.
\end{abstract}

KEY WORDS: pigs, ghrelin, Real-Time PCR, reference genes, stomach

\section{INTRODUCTION}

Real-Time PCR is currently the most precise method for gene expression studies. However, each expression experiment should be preceded by careful

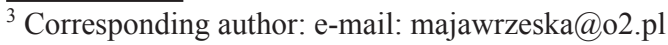


selection of endogenous reference genes (ERGs) to obtain accurate results (Bustin et al., 2009). Endogenous control is a housekeeping gene, expressed in every cell of the organism. Although genes like glyceraldehyde-3-phosphate dehydrogenase $(G A P D H)$, beta actin $(A C T B)$ or hypoxanthine phosphor-ribosyltransferase (HPRT) are commonly used endogenous controls, their expression level often depends on tissue type, developing stage or other factors.

To date, several studies evaluated usefulness of commonly used housekeeping genes to expression analysis of various porcine tissues (Erkens et al., 2006; Kuijk et al., 2007; Nygard et al., 2007; Svobodová et al., 2008). However, no such a study for porcine stomach has been performed.

Stomach is a place of synthesis of many important substances engaged in regulation of appetite, motility of gastrointestinal track and weight gain as a consequence. Hormones like ghrelin, serotonin and gastrin are a part of a complex hormonal axis which regulate animal's growth and reproductivity. Analysis of expression of genes coding for these proteins is necessary to understand mechanisms which control feed intake and weight gain of farm animals. One of the most interesting hormones engaged in feeding regulation is ghrelin - a novel hormone secreted mainly by stomach mucosa (Kojima et al., 1999; Date et al., 2002). It was proved that plasma ghrelin stimulates food intake in man (Wren et al., 2001) and is involved in weight gain in rat, mice (Tschöp et al., 2000) and pigs (Salfen et al., 2004). Ghrelin is also supposed to play a major role in the regulation of reproduction in pigs (Zhang et al., 2008).

The aim of our study was to evaluate usefulness of six reference genes to expression studies of porcine stomach. We selected genes (RPL27- ribosomal protein L27, RPS29 - ribosomal protein S29, RPS13- ribosomal protein S13 and $O A Z 1$ - Ornithine Decarboxylase Antizyme 1) which were described as very stable after analysis expression data from 13,629 published human gene arrays (de Jonge et al., 2007) and two commonly used reference genes (GAPDH, ACTB). Set of three the most stable genes has been used to compare ghrelin expression in two different regions (diverticulum ventriculi and fundus ventriculi) of porcine stomach.

\section{MATERIAL AND METHODS}

Animals for the study (female, prepubertal pigs, with an average body weight of $100 \mathrm{~kg}$ ) were kept in Pilot Plant of the National Research Institute of Animal Production. In total, twenty four animals were examined (seventeen Pietrain and seven Landrace pigs). Two fragments of stomach (diverticulum ventriculi and fundus ventriculi) were collected immediately after slaughter and kept in RNA later 
(Ambion Inc.) during transportation (in total forty eight samples). For evaluation of the stability of reference genes twenty nine samples, taken from 7 Landrace and 16 Pietrain gilts, were chosen (twenty one diverticulum ventriculi and eight fundus ventriculi), while for comparing expression of GHRL gene in two regions of stomach, twenty six samples, taken from 10 Landrace and 3 Pietrain gilts, were chosen (two samples from thirteen animals). All animals were fasted $48 \mathrm{~h}$ before slaughter.

The total RNA was extracted using SV Total RNA Isolation System (Promega), according to manufacturer protocol. The quantity of extracted RNA was estimated by BioPhotometer (Eppendorf), and its quality was evaluated by gel electrophoresis. The purity of RNA was checked by Real-Time PCR with No-RT samples.

The RNA $(1 \mu \mathrm{g})$ was reverse transcribed into cDNA at $37^{\circ} \mathrm{C}$ using High Capacity cDNA Reverse Transcription Kit with random primers (Applied Biosystems).

Primers and probes for RPS13, RPL27, RPS29, OAZ1 and GAPDH were designed by Agata Piestrzyńska-Kajtoch (unpublished data), whereas primers and probes for ghrelin $(G H R L)$ and beta actin $(A C T B)$ were purchased as a TaqMan gene expression assays from Applied Biosystems company (Table 1).

Relative quantification of the expression was performed on 7500 Real-Time PCR System using Gene Expression PCR Master Mix (Applied Biosystems). Reactions, in a total volume of $25 \mu 1$, were performed in triplicate. The protocol included two initial steps: $50^{\circ} \mathrm{C}$ for $2 \mathrm{~min}$ (UNG incubation) and $95^{\circ} \mathrm{C}$ for $10 \mathrm{~min}$ (AmpliTaq Gold activation) and 40 cycles of $95^{\circ} \mathrm{C}$ for $15 \mathrm{~s}$ (denaturation) and $1 \mathrm{~min}$ at $60^{\circ} \mathrm{C}$ (annealing/extending). The results were analysed using Sequence Detection System software v. 1.4 (Applied Biosysytems).

The obtained $\mathrm{Ct}$ values were converted into input data for the geNorm application for identification of the most stable reference genes and normalization factor (NF geometrical mean of the most stable genes) calculation. Stability of reference genes was assessed on the basis of $\mathrm{M}$ value, which is calculated as the average pairwise variation for that gene with all other genes tested (Vandesompele et al., 2002). Lowest $\mathrm{M}$ value indicates the most stable gene. Descriptive statistics $(\mathrm{Ct}$ min, $\mathrm{Ct}$ max, standard deviation, coefficient of variation) of the results were calculated with Bestkeeper software as well as coefficient of correlation with Bestkeeper index (geometrical mean of Ct of analysed genes) (Pfaffl et al., 2004).

Samples of fundus ventricul and diverticulum ventriculi from 13 animals were used for comparison of ghrelin expression level. Relative quantity of ghrelin mRNA was calculated according to Pfaffl (2001). Significance of difference between expression level of mRNA ghrelin in group of fundus ventriculi and diverticulum ventriculi was compared by using two sample T test (Satterthwaite method). Normal distribution of the data was verified by Kolmogorov-Smirnov test. These computations were performed by the use of procedure $\mathrm{T}$ Test of the SAS package programs (2006). 


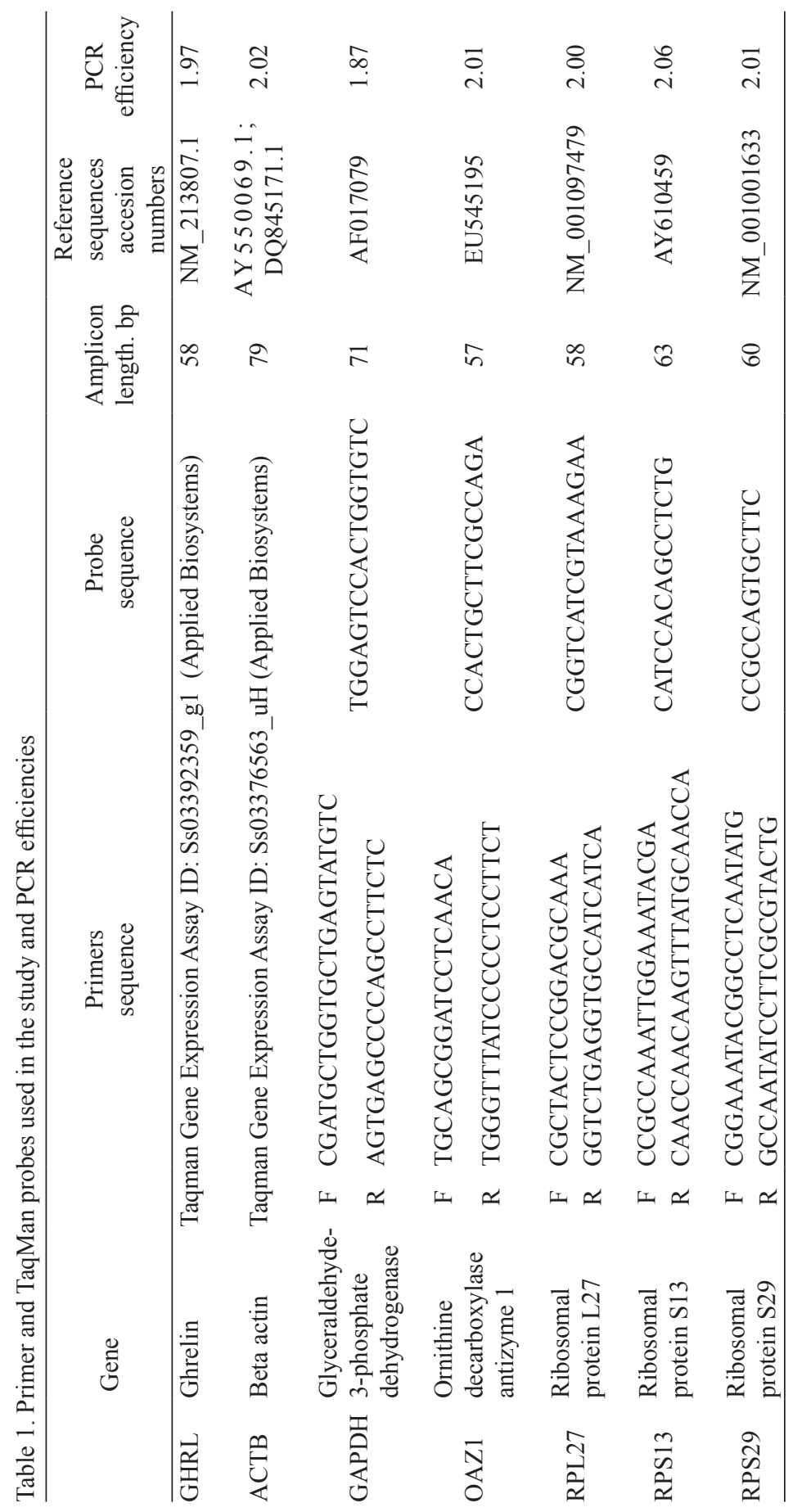




\section{RESULTS}

Twenty nine samples of stomach (21 fundus ventriculi and 8 diverticulum ventriculi) were used for evaluation of the stability of reference genes. According to geNorm software the most stable was $\operatorname{OAZ1}(\mathrm{M}=0,856), \operatorname{RPS} 29(\mathrm{M}=0.862)$ and RPL27(M=0.892). ACTB $(\mathrm{M}=1.03)$ and GAPDH $(\mathrm{M}=1.005)$, commonly used housekeeping genes were less stable, while RPS13 $(\mathrm{M}=1.913)$ appeared to be highly unstable (Table 2). The best correlation between BestKeeper index and candidate reference gene was obtained for OAZ1, RPS29 and RPL27. GAPDH and these three genes had also the lowest standard deviation (SD) and the coefficient of variation (CV), while RPS29 and ACTB had higher SD and CV (Table 2). Our results shows that $O A Z 1, R P S 29$ and $R P L 27$ are more suitable reference genes than $A C T B$ and $G A P D H$ in expression studies of porcine stomach.

Table 2. Expression stability of analysed genes after geNorm and Bestkeeper analysis

\begin{tabular}{lrrrrrr}
\hline Item & OAZ1 & RPL27 & RPS29 & RPS13 & GAPDH & ACTB \\
\hline Min, Ct & 20.891 & 20.013 & 19.433 & 22.157 & 30.216 & 17.212 \\
Max, Ct & 23.327 & 23.135 & 22.51 & 28.559 & 33.838 & 21.122 \\
Standard deviation, \pm Ct & 0.528 & 0.601 & 0.562 & 1.589 & 0.711 & 0.822 \\
Coefficient of variation, \% Ct & 2.399 & 2.831 & 2.731 & 6.403 & 2.231 & 4.387 \\
Coefficient of correlation, $r$ & 0.82 & 0.857 & 0.88 & 0.579 & 0.666 & 0.747 \\
$\quad$ (Bestkeeper) & 0.856 & 0.892 & 0.862 & 1.913 & 1.005 & 1.03 \\
M value, geNorm & & & & &
\end{tabular}

Geometrical mean of three the most stable genes OAZ1, RPS29 and RPL27 were utilized for calculation of normalization factor which was further used for expression level of GHRL gene evaluation. Ghrelin mRNA was highly expressed in both regions of stomach, however level of GHRL mRNA was approximately 5-fold higher in fundus ventriculi than in diverticulum ventriculi (Figure 1).

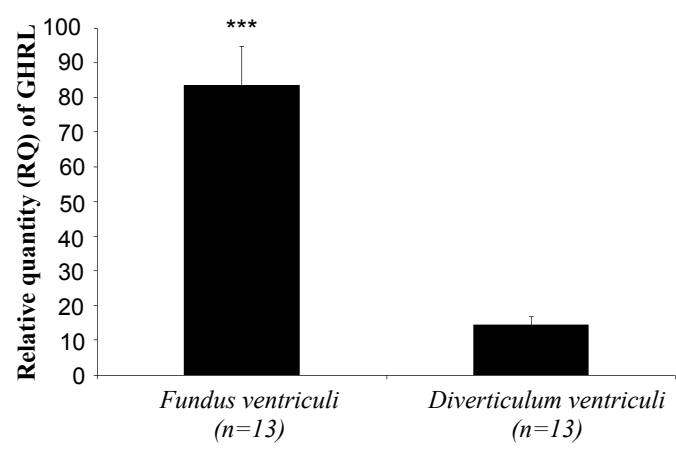

Figure 1. Relative expression of ghrelin (GHRL) in two regions of porcine stomach; $* * *-\mathrm{P}<0.001$ 


\section{DISCUSSION}

Our evaluation of stable endogenous reference genes in porcine stomach is in an agreement with general tendency to normalize Real-Time date against new ERGs rather than traditional (like $A C T B$ or $G A P D H$ ) which is seen in recent publications (Jonge et al., 2007; Kwon et al., 2009). It is very probable that genes selected by us are stable in other organs and tissues of pigs, since they are among top 15 candidate genes after analysis expression data from 13,629 published human gene arrays (de Jonge et al., 2007). One of them, $O A Z 1$, is also present in 13 novel ERGs, selected after analysis of publicly available human gene expression datasets (Kwon et al., 2009). Nevertheless stability of these genes should be carefully analysed in various tissues and experimental conditions, since RPS13 (No 1 in top 15 candidate housekeeping genes (de Jonge et al., 2007)) was unstable in porcine stomach.

Ghrelin is a peptide of 28 amino acids, first identified in rat stomach (Kojima et al., 1999). It plays a crucial role in regulation of many biological functions like food intake, gastrointestinal motility, hormone secretion, glucose and enzymes release. In porcine stomach, ghrelin-immunoreactive cells are most abundant in oxyntic and cardiac glands while less numerous in pyloric glands (Govoni et al., 2005). On the other hand, Hayashida (2001) reported that immunoreactive cells are abundant in all gastric mucosal areas. To date, expression of ghrelin in various parts of porcine stomach has not been studied by Real-Time PCR technique. In our study we compared two regions of stomach, both covered with cardiac glands (Popesko, 1989), however there is a much lower density of cardiac glands on diverticulum ventriculi mucosa than on fundus ventriculi. Our results reflects these differences in cardiac glands distribution on stomach mucosa.

\section{CONCLUSIONS}

In conclusion, we recommend usage of three genes: OAZ1, RPS29 and RPL27 as an endogenous control in gene expression studies of porcine stomach. Our set was validated by analysis of ghrelin expression, which revealed 5-fold higher expression of ghrelin mRNA in fundus ventriculi than in diverticulum ventriculi.

\section{REFERENCES}

Bustin S.A., Benes V., Garson J.A., Hellemans J., Huggett J., Kubista M., Mueller R., Nolan T., Pfaffl M.W., Shipley G.L., Vandesompele J., Wittwer C.T., 2009. The MIQE guidelines: minimum information for publication of quantitative real-time PCR experiments. Clin Chem. $55,611-622$ 
Date Y., Murakami N., Toshinai K., Matsukura S., Niijima A., Matsuo H., Kangawa K., Nakazato M., 2002 The role of the gastric afferent vagal nerve in ghrelin-induced feeding and growth hormone secretion in rats. Gastroenterology 123, 1120-1128

de Jonge H.J., Fehrmann R.S., de Bont E.S., Hofstra R.M., Gerbens F., Kamps W.A., de Vries E.G., van der Zee A.G., te Meerman G.J., ter Elst A., 2007 Evidence based selection of housekeeping genes. PLoS ONE 2(9): e898. doi:10.1371/journal.pone.0000898

Erkens T., Van Poucke M., Vandesompele J., Goossens K., Van Zeveren A., Peelman L.J., 2006. Development of a new set of reference genes for normalization of real-time RT-PCR data of porcine backfat and longissimus dorsi muscle, and evaluation with PPARGC1A. BMC Biotechnol. 6:41doi:10.1186/1472-6750-6-41

Govoni N., De Iasio R., Cocco C., Parmeggiani A., Galeati G., Pagotto U., Brancia C., Spinaci M., Tamanini C., Pasquali R., Ferri G.L., Seren E., 2005. Gastric immunolocalization and plasma profiles of acyl-ghrelin in fasted and fasted-refed prepuberal gilts. J. Endocrinol. 186, 505-513

Hayashida T., Murakami K., Mogi K., Nishihara M., Nakazato M., Mondal M.S., Horii Y., Kojima M., Kangawa K., Murakami N., 2001. Ghrelin in domestic animals: distribution in stomach and its possible role. Domest. Anim. Endocrinol. 21, 17-24

Kojima M., Hosoda H., Date Y., Nakazato M., Matsuo H., Kangawa K., 1999. Ghrelin is a growthhormone-releasing acylated peptide from stomach. Nature 402, 656-660

Kuijk E.W., du Puy L., van Tol H.T., Haagsman H.P., Colenbrander B., Roelen B.A., 2007. Validation of reference genes for quantitative RT-PCR studies in porcine oocytes and preimplantation embryos. BMC Develop. Biol. 7:58doi:10.1186/1471-213X-7-58

Kwon M.J., Oh E., Lee S., Roh M.R., Kim S.E., Lee Y., Choi Y.L., In Y.H., Park T., Koh S.S., Shin Y.K., 2009. Identification of novel reference genes using multiplatform expression data and their validation for quantitative gene expression analysis PLoS ONE 4 (7): e6162. doi:10.1371/ journal.pone. 0006162

Nygard A.B., Jørgensen C.B., Cirera S., Fredholm M., 2007. Selection of reference genes for gene expression studies in pig tissues using SYBR green qPCR. BMC Mol. Biol. 8, 67

Pfaffl M.W., 2001. A new mathematical model for relative quantification in real-time RT-PCR. Nucl. Acid. Res. 29, e45

Pfaffl M.W., Tichopad A., Prgomet C., Neuvians T.P., 2004 Determination of stable housekeeping genes, differentially regulated target genes and sample integrity: BestKeeper--Excel-based tool using pair-wise correlations. Biotechnol. Lett. 26, 509-515

Popesko P., 1989. Atlas of Topographical Anatomy of Domestic Animals (in Polish). PWRiL, Warszawa

Salfen B.E., Carroll J.A., Keisler D.H., Strauch T.A., 2004. Effects of exogenous ghrelin on feed intake, weight gain, behavior, and endocrine responses in weanling pigs. J. Anim. Sci. 82, 19571966

SAS, 2006. SAS Enterprise Guide 4.1 (4.1.0.1000). SAS Institute Inc. Procedure T Test. Carry, NC

Svobodová K., Bílek K., Knoll A., 2008. Verification of reference genes for relative quantification of gene expression by real-time reverse transcription PCR in the pig. J. Appl. Genet. 49, 263-265

Tschöp M., Smiley D.L., Heiman M.L., 2000. Ghrelin induces adiposity in rodents. Nature 407, 908-913

Vandesompele J., De Preter K., Pattyn F., Poppe B., Van Roy N., De Paepe A., Speleman F., 2002. Accurate normalization of real-time quantitative RT-PCR data by geometric averaging of multiple internal control genes. Genome Biol. 3 (7): RESEARCH0034

Wren A.M., Seal L.J., Cohen M.A., Brynes A.E., Frost G.S., Murphy K.G., Dhillo W.S., Ghatei M.A., Bloom S.R., 2001. Ghrelin enhances appetite and increases food intake in humans. J. Clin. Endocrinol. Metab. 86, 5992-5995

Zhang W., Lei Z., Su J., Chen S., 2008 Expression of ghrelin in the porcine hypothalamo-pituitaryovary axis during the estrous cycle. Anim. Reprod. Sci. 109, 356-367 